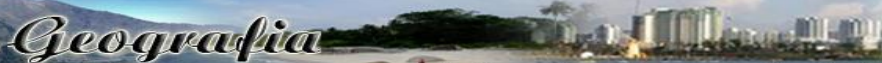

Malaysian Journal of Society and Space

\section{Analyzing the factors and effects of water supply disruption in Penang Island, Malaysia}

\author{
Muhammad Fakruhayat Ab Rashid ${ }^{1}$, Azimah Abd Rahman ${ }^{1}$, Siti Masayu Rosliah Abdul Rashid ${ }^{2}$ \\ ${ }^{1}$ Geoinformatic Unit, Geography Section, School of Humanities, Universiti Sains Malaysia \\ ${ }^{2}$ School of Distance Education, Universiti Sains Malaysia
}

Correspondence: Azimah Abd Rahman (email: azimahrahman@usm.my)

Received: 08 March 2021; Accepted: 14 July 2021; Published: 27 August 2021

\begin{abstract}
Water resources are nature's most precious gift in life on this earth. Humans need to have ethics in environmental development to caring the environment. The rapid development to meet human needs and requirements has caused the source of clean water supply to be more limited and threatened. This study aims to analyze the factors and effects of water supply disruption to the community in Penang Island. This study employs a quantitative approach, with a survey consisting of 100 questionnaires distributed to respondents. The study also uses an informal interview method that records some of the respondents' thoughts and opinions about the research issues. Respondents were selected randomly to be involved in the data collection process. The results of the data were analyzed to obtain the value of frequency, percentage, mean, std. deviation, and descriptive analysis. According to the study's findings, the most influential factor of disruption of water supply consumption is a lack of capacity of the water treatment plants, which recorded a total mean $=4.36$, and the least influential factor is weaknesses in water management, which recorded a total mean=3.48. The most dominant effect of water supply disruption is the disease that affects health, with a mean score of 4.30, the least influential effect is a reduction in the life of flora and fauna, with a mean score of 3.61. This study has the potential to provide information to authorities and stakeholders in formulating strategies and interventions for the well-being of the community. The recommendation for future studies is to further expand the scope of the study which is to add more survey stations and the number of samples to describe the actual population.
\end{abstract}

Keywords: Disruption factors, effects, Penang Island, water supply

\section{Introduction}

Globally, sustainable management of water resources is required to avoid widespread water shortage. A variety of human pressures such as urbanization, intensive agriculture, overabstraction, inefficient distribution, and extraordinary demand have underpinned climate change, pollution, and biodiversity loss, all of which contribute to water shortage (Saeid Eslamian \& Faezeh Eslamian, 2017). In Malaysia, the average annual rainfall received is around $2500 \mathrm{~mm}$ to $3000 \mathrm{~mm}$ which has the potential to cause floods (Hashim et al., 2017). 
However, this situation has caused the society to misjudge the amount of water resources available by assuming that Malaysia has abundant water supply resources (Hanafiah et al., 2019).

Water consumption in Malaysia for domestic purposes is $61.6 \%$ of the total treated water which shows a high domestic water consumption because it exceeded $50 \%$ of the total treated water (Hamid, 2015). Penang Island is the state that records the highest domestic water supply consumption in Malaysia (Hanafiah et al., 2019). The average domestic water consumption in Penang Island has recorded a total of 293 litres in 2014 (Hezri, 2018). One of the factors of high water supply consumption in Penang Island is due to low water tariffs for domestic and commercial usage. Penang Island's water tariff is the lowest in Malaysia with RM0.32 per 1,000 litres for the first 35,000 litres per month of usage (Tan, 2019).

According to PBAPP, in 2018 a total of 1,073 million litres per day (MLD) were produced from Sungai Muda raw water and other raw water sources in Penang Island (Tan, 2019). The water demand made by PBAPP until 2050 is estimated at 1,883 MLD (Dermawan, 2019). Sungai Muda which supplies the main raw water source for Kedah, Perlis, and Penang Island is predicted to only be able to meet the raw water needs of each state until 2025 (Dermawan, 2019). According to Husain et al. (2017), the water catchment area in Penang Island is only able to supply $30 \%$ of the total water while the remaining $70 \%$ of the total water is supplied from Sungai Muda. However, chief executive officer of PBAPP, stated that it could no longer support Sungai Muda river level during the ongoing dry season, leaving Sungai Muda river to be largely dependent on only one dam; Beris Dam (Dermawan, 2020). The population growth of Penang Island has grown at an average rate of $1.7 \%$ per annum from 2000 to 2010. This situation has caused water supply pressure in Penang Island. This population growth has led to an increase in water consumption which could affect the water supply sources in the future (Osman et al., 2017).

This study has been undertaken to understand the factors and effects of water supply disruption on the community in Penang Island, Malaysia, in the context of the lack of water treatment plant, leaking water pipes, prolonged hot weather, diseases, access to food supplies and so on. Therefore, 6 study locations have been selected in an effort to study the factors and effects of water supply disruption on the community in Penang Island. The methodology of the research implemented is a mixed method distributed to 100 respondents in order to get the data. This method is quantitative (questionnaire) and qualitative (informal interview).

\section{Literature review}

The main source of water supply in Malaysia is rainwater, which makes about $90 \%$ of Malaysia's water supplies (EPU, 2010). Malaysia has seen an unprecedented demand on its water supplies due to fast economic expansion (Anang et al., 2019). Most of the supply is focused on agriculture, which consumes $76 \%$ of the total water supply. Malaysia's water consumption is predicted to exceed 20 billion $\mathrm{m} 3$ by 2020 , with agriculture being the dominant consumer. To prepare for this, the emphasis should be on improving the water usage management rather than water supply management. Figure 1 shows that from 1980 to 2020, the demand for water in numerous areas such as domestic and industrial, irrigation, and other industries has increased. In 1980, Malaysia's total water usage was 8.9 billion billion m3, with irrigation accounting for about $83 \%$ of total water use. Water usage increased to 11.8 billion $\mathrm{m} 3$ in 1990 due to agricultural, industrial, and domestic uses. Water consumption progressively increased to 15.5 billion $\mathrm{m} 3$ in 2000 (Anang et al., 2019). 


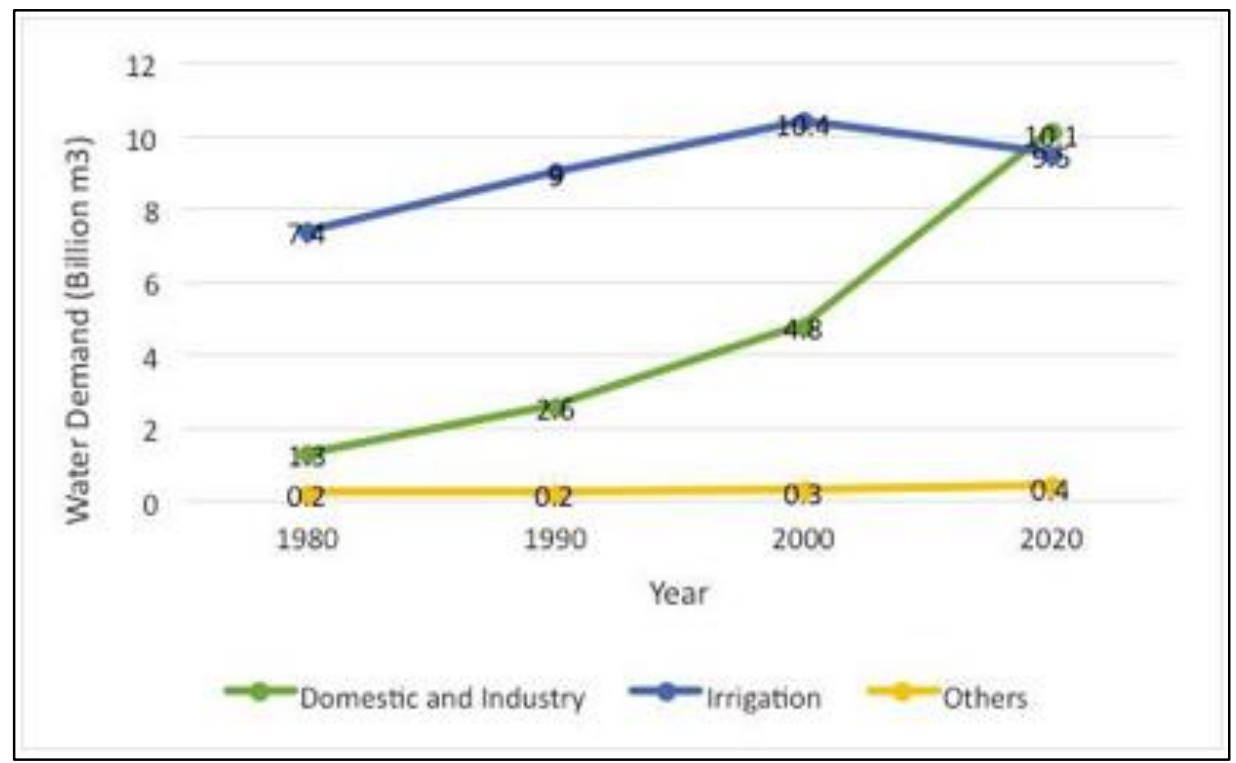

Source: (Anang et al., 2019)

Figure 1. The Demand for water in different sectors in Malaysia from 1980 to 2020.

Between 1980 and 2000, annual domestic and industrial use of water grew by $12 \%$ (EPU, 2006). In the 2000s in Malaysia, the usage of hydropower, transportation and leisure activities tripled. There has been greater attention on this. The largest demand for water was for agriculture, which accounted for $67 \%$ of the total water use from 1980 to 2000. Since 2000, this number has decreased. According to The Comprehensive Assessment of Water Management in Agriculture, Malaysia has a water scarcity crisis, with the third of Malaysians experiencing water shortages in 2007 (Anang et al., 2019). In Malaysia, the demand for water resources increased from $1980\left(8.9\right.$ billion $\left.\mathrm{m}^{3}\right)$ to $2000\left(15.5\right.$ billion $\left.\mathrm{m}^{3}\right)$ in agricultural, industrial, and domestic activities. Furthermore, in developed countries, the agricultural sector has absorbed up to $76 \%$ of water resources, with up to $90 \%$ being used for the irrigation for paddy production and heavy industry. The increasing population and urbanization will also lead to aggravate the water shortage because of water demands (Chen et al., 2020).

Nevertheless, new water problems such as pollution, destruction of water catchment areas, water waste, high non-revenue water (NRW), low tariffs, and a lack of public knowledge on water conservation have led to Malaysia's water resources to decline (Chan, 2004). According to Lai et. al (2016), Malaysia's NRW problem is not only a technological issue, but also a matter of poor governance and management. The research reveals that when it comes to water policy, public engagement is usually undervalued. Several positive stories have emerged from Malaysia's water utilities in terms of public engagement as a solution to the NRW problem.

Raising water fees is a politically controversial topic in Malaysia. For the first 40,000 litres of water, the household water rate in Penang Island is 0.35 MYR cents or 0.08 US cents while the home water tariff in Perlis is 0.59 Malaysian cents, which is equal to 0.14 US cents. Malaysians have not exercised water conservation, since home water use in most states exceeds 220 L per capita per day. Ahmed et al. (2020) also reported that Malaysian people are well aware of the river pollution and drinking water contamination. However, negative impacts of NRW issues on the public are mostly delayed or indirect, leading to poor public awareness of this issue. Lai et al. (2016) suggested that if somehow the public is aware of the health and economic benefits of the enhanced water supplies, they are more likely to pay for them. 


\section{Research methodology}

\section{Study area}

The researchers have chosen Penang Island $\left(5.4164{ }^{\circ} \mathrm{N}, 100.3327^{\circ} \mathrm{E}\right)$ as the study area to study the disruption of water supply consumption in Penang Island. Among the areas that are under study by researchers in the state of Penang Island are Komtar, Universiti Sains Malaysia (USM), Sungai Dua, Sungai Nibong, Bukit Jambul, and Bayan Lepas. This study area is very suitable as the factors and effects of disruption of water supply consumption in Penang Island can be referred to (Figure 2).

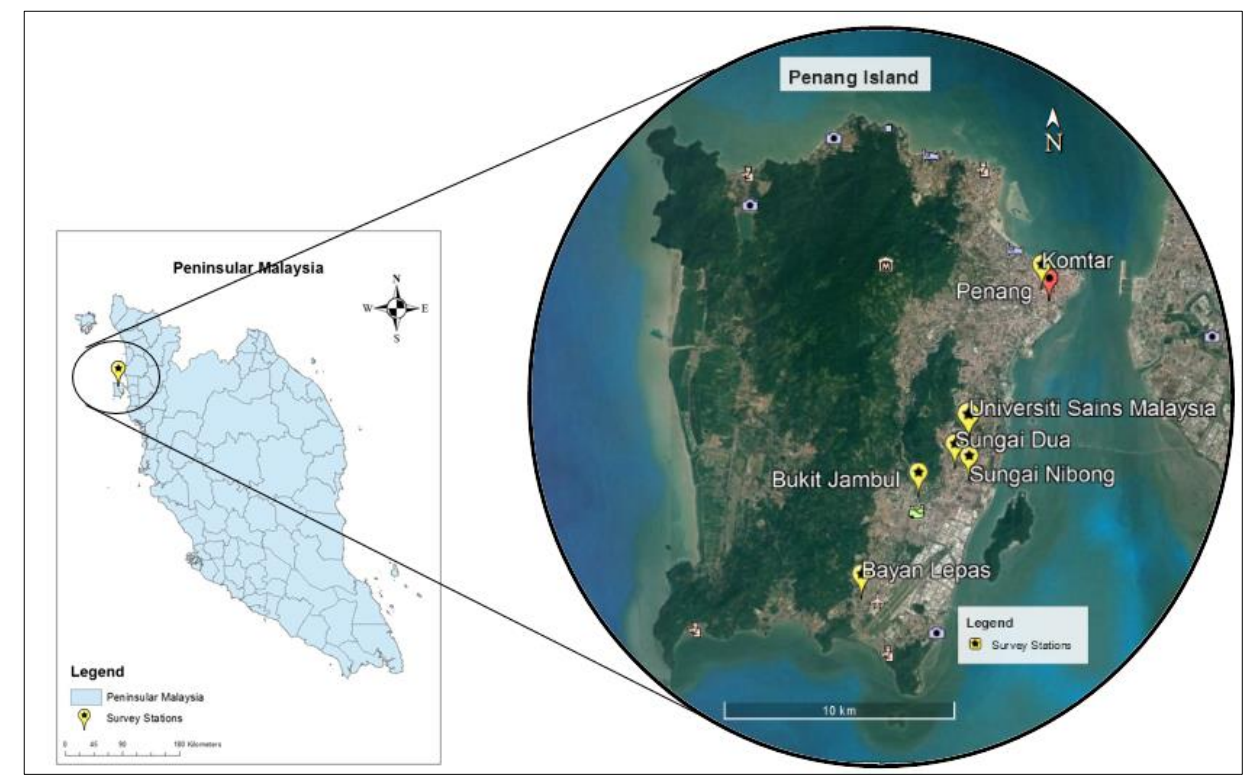

Figure 2. The map of survey stations.

\section{Research design}

The diagram below shows the research framework (Figure 3) and the conceptual framework (Figure 4). To obtain the study findings, researcher employed two techniques of data collecting, namely primary data and secondary data, as shown in the research framework. Meanwhile, the conceptual framework shows a research of analyzing the factors and effects of water supply disruption in Penang Island, Malaysia, by using items of questionnaire to determine which factors and effects are the most influential on water supply disruption. 


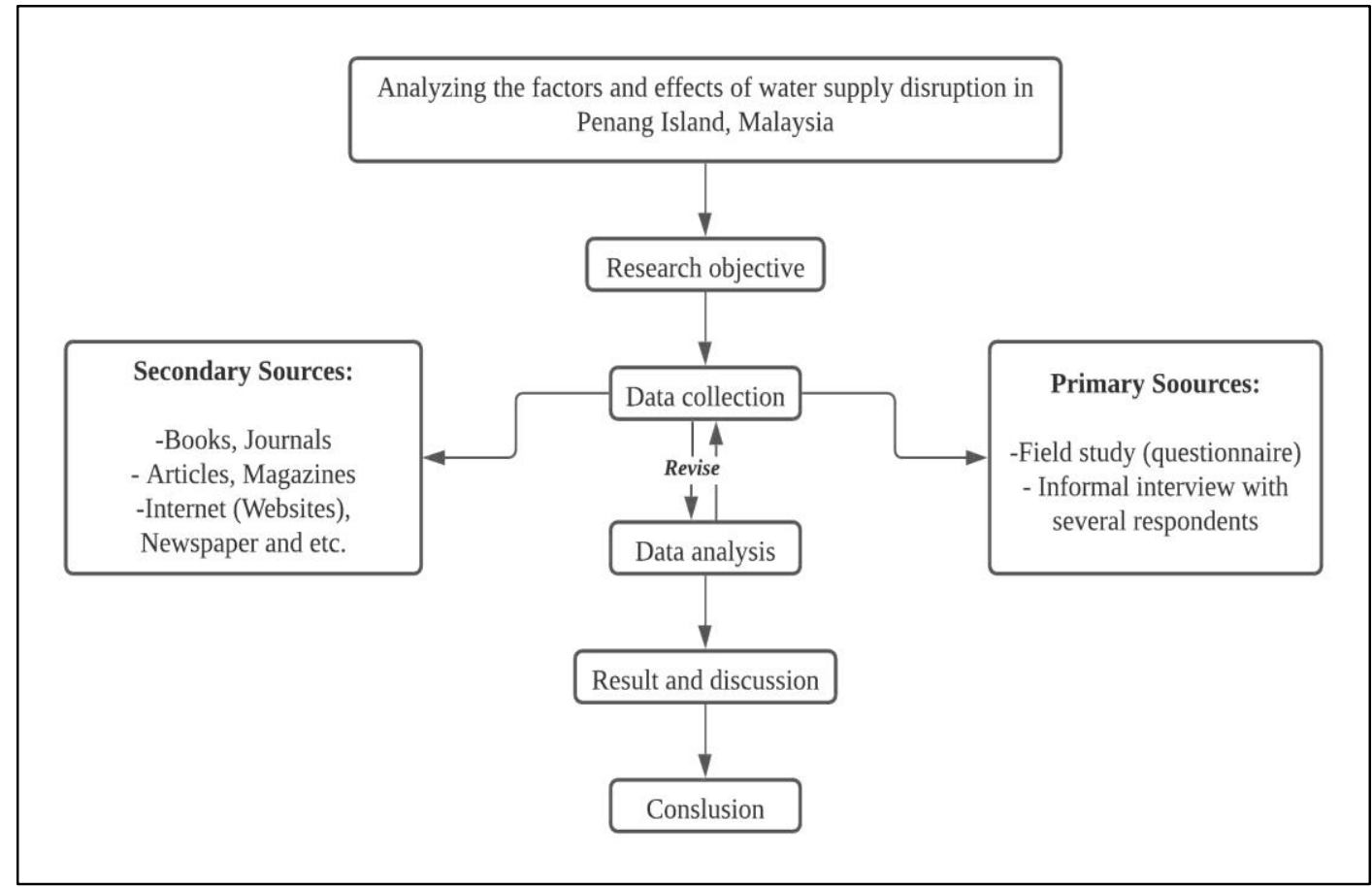

Figure 3. Research framework.

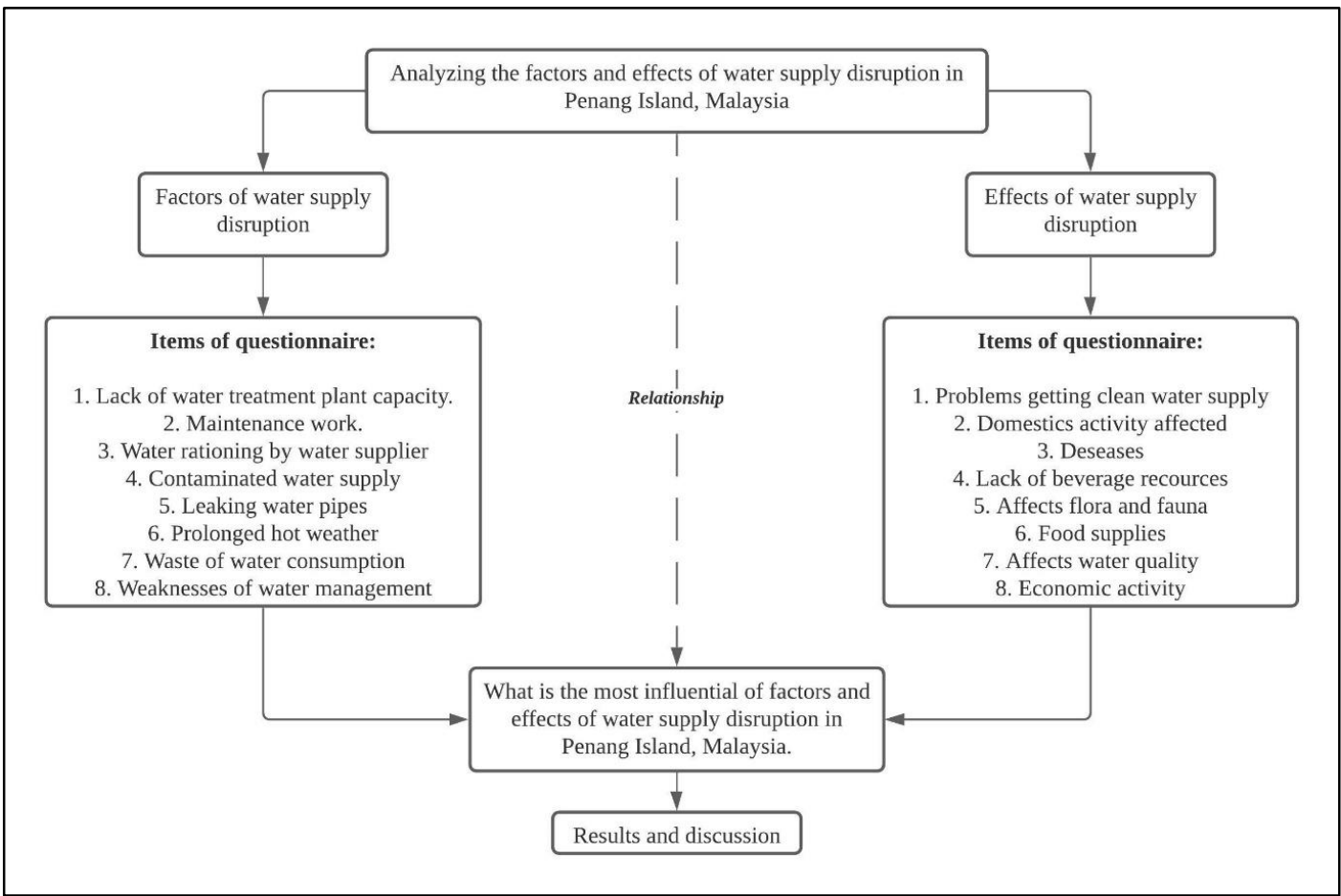

Figure 4. Conceptual framework

\section{Data collection}

This study uses two types of data sources, namely primary data and secondary data. Primary data were obtained through a questionnaire session with respondents. The researcher selected the study respondents based on random sampling. In this random sampling method, the researcher needs to identify the selected study sample, makes a complete list of the selected 
sample and select the sample based on the opportunity and probability of the population to be the sample in this study.

Respondents must be of various races, ages, educational levels, and family sizes. Therefore, a questionnaire session was conducted to obtain feedback from the respondents. Questionnaire sessions were conducted over a period of two weeks starting February 2, 2020 and ending on February 15, 2020. Initially, a total of 150 questionnaires was distributed to the respondents involved. Only 150 questionnaires were distributed as researchers had the time constraints in collecting information. However, after some consideration on all the information in the questionnaire, the researcher determined that the respondents involved in this study are only 100 people and represent the six areas involved. The researcher hopes that the sample size of 100 respondents can reflect the actual population and represent the six study areas involved.

This study also used secondary data. Secondary data were obtained through books, articles, journals, newspapers related to water problems and research topics. In addition, data from the Penang Water Supply Corporation (PBAPP) website, and the National Water Services Commission (SPAN) were also requested for more detailed information (Figure 5).

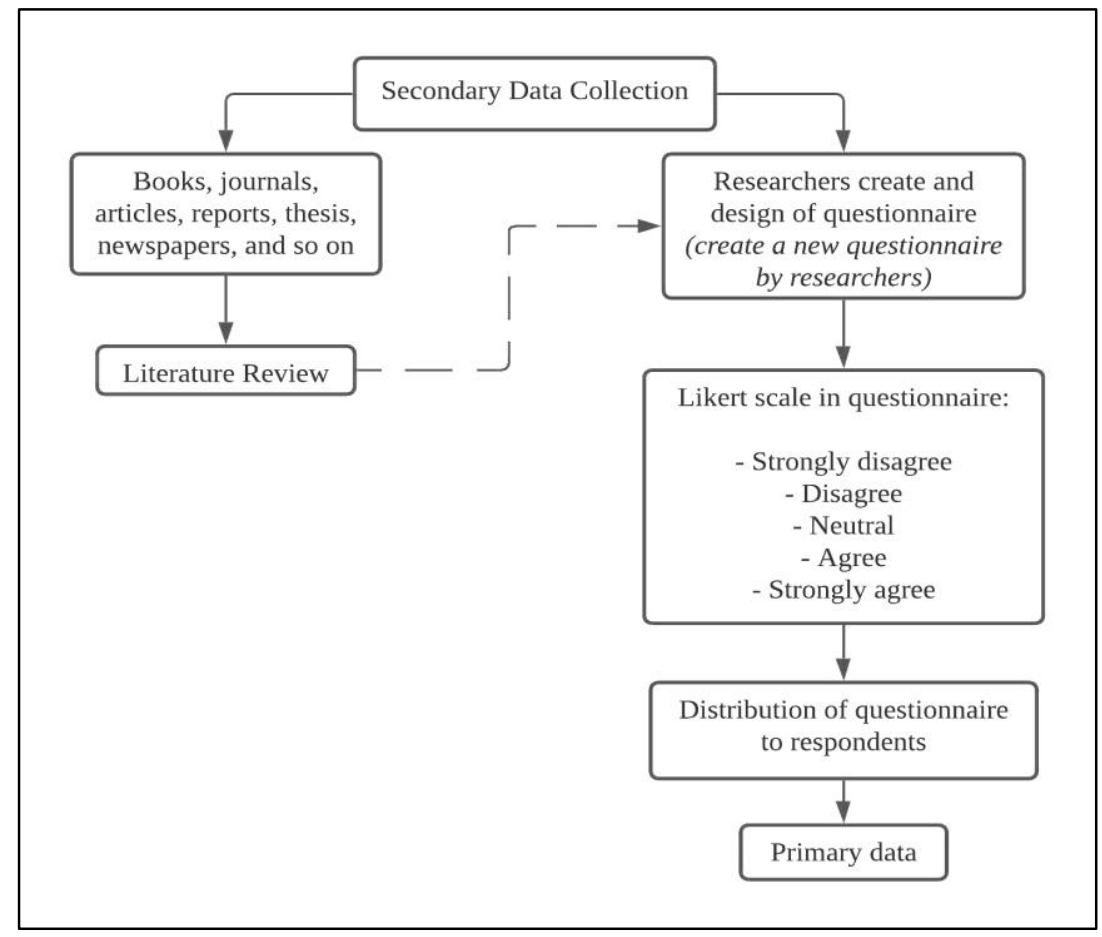

Figure 5. Data collection method.

\section{Data processing}

The researchers used computers with software known as Statistical Package for the Social Sciences (SPSS) to analyze the data to help researchers to obtain descriptive analysis, frequency data, and the mean. ArcMap software was used to map the survey stations in this research. The study area location data in MS Excel was put into ArcMap to map the research location. Tests were also performed to obtain the Cronbach's Alpha values. Reliability test is a test that refers to the consistency and stability used as a test of a concept (Pallant, 2010).

\section{Results and discussion}

\section{Demographic of respondents}


Table 1 shows the demographics of the respondents. The results of the data analysis collected through questionnaires show that the gender of the population in the selected area is more dominated by women which is $60 \%$ and men only for $40 \%$ of the total respondents. In terms of age, researchers see that most of the population age are in the range of 15-30 years with $48 \%$ while the minority age in the range of $43-64$ years which is $8 \%$. The age demographic pattern is such because the area is an urban area and a developed settlement due to the presence of educational centres, industry, tourism and there are quite a number of young people in the area as they tend to migrate to urban areas.

Table 1. Demographic of respondents.

\begin{tabular}{|c|c|c|}
\hline Demographic Profile $(\mathbf{N}=\mathbf{1 0 0})$ & Frequency & $\%$ \\
\hline \multicolumn{3}{|l|}{ Gender } \\
\hline Male & 40 & 40.0 \\
\hline Female & 60 & 60.0 \\
\hline \multicolumn{3}{|l|}{ Age } \\
\hline 15 - 30 years & 48 & 48.0 \\
\hline $31-42$ years & 44 & 44.0 \\
\hline $43-64$ years and above & 8 & 8.0 \\
\hline \multicolumn{3}{|l|}{ Race } \\
\hline Malay & 59 & 59.0 \\
\hline Chinese & 26 & 26.0 \\
\hline India & 15 & 15.0 \\
\hline \multicolumn{3}{|l|}{$\overline{\text { Educational Level }}$} \\
\hline SPM & 16 & 16.0 \\
\hline STPM / Diploma & 60 & 60.0 \\
\hline Degree & 24 & 24.0 \\
\hline \multicolumn{3}{|l|}{ Job Status } \\
\hline Unemployed & 39 & 39.0 \\
\hline Private sector & 25 & 25.0 \\
\hline Government agencies & 22 & 22.0 \\
\hline Private business & 14 & 14.0 \\
\hline \multicolumn{3}{|l|}{ Montly Income B40 (RM) } \\
\hline B1 less than 2,500 & 68 & 68.0 \\
\hline B2 2,501-3,169 & 16 & 16.0 \\
\hline B3 $3,170-3,969$ & 13 & 13.0 \\
\hline B4 3970-4849 & 3 & 3.0 \\
\hline \multicolumn{3}{|l|}{ Type of Residence } \\
\hline Housing & 22 & 22.0 \\
\hline Apartment & 20 & 20.0 \\
\hline Low cost houses / Flat & 34 & 34.0 \\
\hline Terraced house & 16 & 16.0 \\
\hline Bungalow & 1 & 1.0 \\
\hline Condominiums & 7 & 7.0 \\
\hline \multicolumn{3}{|l|}{ Number of Households (People) } \\
\hline $1-2$ & 34 & 34.0 \\
\hline $3-4$ & 53 & 53.0 \\
\hline 5 and above & 13 & 13.0 \\
\hline
\end{tabular}

Meanwhile, the largest group of race staying in the area selected in Penang Island is the Malay which is $59 \%$, followed by the Chinese $26 \%$ and Indians $15 \%$. For education category, the data collected from the respondents showed that most of the respondents had an STPM/Diploma educational background of $60 \%$ of the total and the least was SPM or by percentage, $16 \%$. For Degree category, the total percentage of respondents was $24 \%$. Most of the respondents have a high educational background because the researchers distributed many questionnaires in educational centres such as in the study area that they chose, namely in USM. 
In terms of job status, it shows that most respondents are unemployed which is $39 \%$. The lowest employment status is in the private business $14 \%$. The private sector recorded a total percentage of $25 \%$ respondents and government agencies a total percentage of $22 \%$ respondents.

In terms of the total monthly income of the respondents, it shows that most of the respondents have a lower income of less than RM2500, which is a total of 68 respondents. The minimum income of the respondents shown by Table 1 is around RM3970 to RM4849 which is represented by 3 respondents only. Based on the researchers' observation, this is because the average population or respondents among students, civil servants, private and residents working in business is very few. Next, the majority of respondents live in low cost houses or flat type housing residences with 34 respondents. The lowest type of residence is represented by bungalow which is 1 respondent. The average number of households which is 3 to 4 people is 53 respondents and they are the most dominant. The total number of households of 5 and above is 13 respondents. This indicates that most of the respondents are married couples.

\section{The factors of water supply disruption on the community in Penang Island}

Table 2 shows the variables that influence the factors of water supply disruption in Penang Island, Malaysia. The analysis data shows that the most dominant and the highest factor is due to the lack of capacity of water treatment plants which recorded a total mean $=4.36$. A total of $62.9 \mathrm{~km}^{2}$ of land in the state of Penang Island is reserved as a water catchment area which represents $6 \%$ of the total land area in the state. However, this water catchment area only supplies about $20 \%$ of the clean water needs in Penang Island. The remaining $80 \%$ is supplied by the Sungai Dua and Sungai Muda plants in Kedah (Leng et al., 2013). Based on a media statement issued by PBAPP on 15 April 2020, the Penang Island state government has made an application to the Meteorological Department to immediately implement cloud seeding to trigger more rain in Penang Island and Kedah due to unusually dry weather since 2019. This is because the effective capacity of 6 major dams in Penang Island and Kedah is very low (Bernama, 2020).

Table 2: Factors of disruption of water supply consumption.

\begin{tabular}{lcc}
\hline $\begin{array}{l}\text { Factors of disruption of water supply } \\
\text { Descriptive Analysis (N = 100) }\end{array}$ & Mean & Std. Deviation \\
\hline Lack of water treatment plant capacity & & \\
Maintenance work & 4.36 & .718 \\
Water rationing by water managers & 4.27 & .664 \\
Contaminated water supply & 3.83 & .975 \\
Leaking water pipes & 3.58 & 1.056 \\
Prolonged hot weather & 3.97 & .926 \\
Waste of water consumption & 4.24 & .842 \\
Weaknesses of water management & 4.13 & .906 \\
\hline
\end{tabular}

Meanwhile, according to the findings of the study, the lowest factor influencing the disruption of water supply is the weakness of water management with a record of mean $=3.48$ (Table 2). The issue of water management flaws plays an important role in ensuring that the water supply is maintained. The National Water Services Commission (SPAN) has identified various weaknesses in addressing the issue of NRW in Malaysia (Sakke et al., 2020). There is no active leakage control programme or planning, a small maintenance allocation, a lack of competent staff, poor asset management, unsystematic implementation and maintenance of the water supply system, weaknesses in the information technology system, weaknesses in the data 
collection system, poor understanding of leakage management, and water not being regarded as a valuable commodity (Sani \& Rindam, 2017). The raw water is gravity-drawn from the Teluk Bahang Dam to the treatment plant via a $3.4 \mathrm{~km}$ transfer tunnel. The Teluk Bahang Dam was chosen as its water source due to the fact that it is a less polluted and contaminated catchment area (Omran, 2011).

Furthermore, the water supply disruption factor caused by maintenance work has a mean score of 4.27 (Table 2). The maintenance works include repairing pipe leaks, repairing piped water drainage systems and so on. Meanwhile, the factors, in terms of water rationing by the management of water and contaminated water supply, recorded a mean of 3.83 and 3.58 respectively (Table 2). Besides that, the disruption factor of the water supply caused by leaking water pipes has a mean record of 3.97 (Table 2). As a solver, water management methods can be used through water-saving tools such as installing efficient water equipment, repairing water leaks, using automatic pipes, using water buckets to wash cars and so on (Chan, 2008).

Furthermore, the disruption to water supply sources has been impacted by prolonged hot weather and waste of water consumption, which recorded a total mean of 4.24 and 4.13, respectively (Table 2). According to Ramli (2021), Penang Island is currently in the annual dry season, with rain only expected in April or May 2021. Although Malaysia receives a large amount of rainfall which is an average of between 2,000 and 3,000mm per year, not all rain drops in rainwater catchment areas and rainfall distribution are uneven throughout the year (Leng et al., 2013).

The comparison between the factors that causes the water supply disruption with other studies conducted by Leng et al. (2013), is due to the low level of awareness about water problems in their residential areas. The results of a study by Leng et al. (2013) showed that $68.1 \%$ of domestic water users in Penang Island are unaware of the water problems that occur in their area (Table 3).

Most people in Penang Island do not know or have no comment on the water issues that occur due to the less involvement in the decision-making in water management (water demand) and more focus on water supply management. According to the study, it is found that $88.8 \%$ of the people do not know how much amount of water is used each month. This situation shows that the community does not care about water consumption because the cheap water tariff rate of RM0.31 per 1,000 litres causes the community to no longer appreciate this valuable resource (Leng et al., 2013).

Table 3: Water problems in residential areas

\begin{tabular}{ccccc}
\hline & & & $\begin{array}{c}\text { Valid } \\
\text { Percentage }\end{array}$ & $\begin{array}{c}\text { Cumulative } \\
\text { Percentage }\end{array}$ \\
Water problem & Frequency & Percentage & & \\
\hline Quality Issues & 110 & 13.6 & 13.6 & 13.6 \\
Tariff issues & 2 & 0.2 & 0.2 & 13.8 \\
Water Cut & 19 & 2.3 & 2.3 & 16.2 \\
Service Problem & 6 & 0.7 & 0.7 & 16.9 \\
Blocked & 35 & 4.3 & 4.3 & 21.2 \\
Pollution & 14 & 1.7 & 1.7 & 23.0 \\
Leaks & 40 & 4.9 & 4.9 & 27.9 \\
Lack of water resources & 6 & 0.7 & 0.7 & 28.6 \\
Other & 18 & 2.2 & 2.2 & 30.9 \\
No comment & 519 & 64.1 & 64.1 & 94.9 \\
Don't know & 32 & 4.0 & 4.0 & 98.9 \\
Water awareness & 9 & 1.1 & 1.1 & 100.0 \\
Total & 810 & 100.0 & 100.0 & \\
\hline
\end{tabular}

Source: (Leng et al, 2013) 


\section{The effects of water supply disruption on the community in Penang Island}

Table 4 shows the effect variables that arise from the water supply disruptions that occur. The global demand for water supply has increased over the last 60 years due to a variety of factors such as rapid population and economic growth (Kaur et al., 2010), urbanization and industrialization (Biswas, 2010), land use change (Sophocleous, 2004), intensive farming practices (Tilman et al., 2002), and environmental degradation (Vorosmarty, 2000). Moreover, changes in the frequency, duration, and intensity of drought episodes have resulted in a significant reduction in water resource reserves in numerous locations (Rose \& Rahimi, 2017).

According to the findings of this study, the majority of respondents agreed that a disruption in water supply is equivalent to causing a disease that is easy to reproduce and can affect health with a mean score $=4.30$. According to Rose $\&$ Rahimi (2017), the problem of a lack of water due to drought can have an impact on health. The level of health is highly dependent on the quality of the water usage. River water quality and pollution need to be addressed because $98 \%$ of total water consumption is from rivers (Huang et al., 2015). The results of a study conducted by Rose \& Rahimi (2017) found that the majority of respondents suffer from health problems due to drought.

Table 4: Effects of disruption of water supply consumption.

\begin{tabular}{lcc}
\hline $\begin{array}{l}\text { Effects of disruption of water supply consumption: } \\
\text { Descriptive Analysis (N = 100) }\end{array}$ & Mean & $\begin{array}{c}\text { Std. } \\
\text { Deviation }\end{array}$ \\
\hline Problems getting clean water supply & 4.11 & 1.091 \\
Domestic activity of the community will be affected & 3.83 & 0.817 \\
Diseases are easy to reproduce & 4.30 & 0.823 \\
Lack of beverage (drinking) resources & 3.95 & 1.086 \\
Affects the life of flora and fauna & 3.61 & 1.034 \\
Affects access to food supplies & 3.63 & 1.098 \\
Affects water quality until contaminated & 3.77 & 1.062 \\
Economic activity is affected & 3.98 & 1.025 \\
\hline
\end{tabular}

Furthermore, Table 4 shows that the least influential effect of water supply disruption is the life of flora and fauna affected which recorded a total mean $=3.61$ (Table 4). Besides, the other effects that arise as a result of the disruption of water supply is the problem of obtaining clean water supply which recorded a total mean $=4.11$ (Table 4). In Malaysia, the main source of raw water that is tapped is the rivers that are under the jurisdiction of the respective state governments. Due to developments in the industrial sector, river water quality is deteriorating, resulting in pollution (Huang et al., 2015). To address this problem, the Environmental Quality Act, 1974 stipulates a stricter regulatory compliance for wastewater disposal premises located upstream of a water intake point (Baginda \& Zainudin, 2009).

The findings of the study revealed that the consequences of water supply will have an impact on the community's domestic activities, with a total mean of 3.83 (Table 4). According to Rose \& Rahimi (2017), when an El Nino phenomenon occurs it will cause human daily activities to be affected, which impacts their economy. The results of the analysis on the lack of beverage resources (drinking water) show a mean $=3.95$. Human activity has caused a growing number of contaminants into water supplies in both developing and developed countries, such as heavy metals, pharmaceuticals, endocrine disruptors, perfluorinated compounds, flame retardants, and biocides (Ternes et al., 2015). The treated drinking water is supplied with physical load(s), microbial load (cells) and nutrient loads (organic and inorganic nutrients) into the distribution system (Prest et al., 2016). Distribution is as crucial as 
production in the provision of drinking water because the quality of tap water is only as good as the condition of the pipes through which it runs (Ainsworth, 2013).

Meanwhile, access to food supply was affected showing a total mean $=3.63$ (Table 4). As available water supplies grow scarce, the demand for irrigation water will rise in regions where agricultural systems rely largely on irrigation. Irrigated agriculture is currently the world's greatest water user, accounting for more than $70 \%$ of total withdrawn water (FAO, 2013). In developing countries where rural economies rely primarily on agricultural products, intensive irrigated agriculture consumes more than $90 \%$ of the water (Samian et al., 2015). A continuous policy of rational irrigation development is required because reductions in irrigation water availability and demand represent a significant danger to national food security (Kang et al., 2016) and will increase rural poverty and forced migration if not carefully planned.

The results of the analysis related to water quality show a total mean $=3.77$ (Table 4). Based on the results of a study conducted by Leng et al. (2013), it is found that $13.6 \%$ of respondents stated that water problems in their homes were due to smelly and dirty water, and these are quality problems. This situation is not only happening in Penang Island but throughout Malaysia where the water quality is not safe to drink. The deterioration of water quality is due to old pipelines installed in Malaysia (KeTTHA, 2009).

The findings of the effects of water supply disruption will result in affected economic activity with a mean $=3.98$ (Table 4 ). The results of a study conducted by Rose \& Rahimi (2017), stated that most respondents agreed that drought can affect sources of income. The results of the study also show that the population have started to be aware in terms of finances and sources of income. Water scarcity is threatening the economic development, sustainable human life, environmental quality, and social activities all over the world (Omran, 2011).

\section{Discussion}

This research finding indicate that the most influential factors of disruption of water supply consumption is the lack of capacity of water treatment plants and the least influential factors is because of the weaknesses in water management. The main factor of water shortage is because most people are not really concerned about the water they are using, as the water bill is only a small component of their monthly household expenses. According to study by Leng et al. (2013) most people in Penang Island do not know about the water issues that occur due to their less involvement in decision-making in water management (water demand) and more focus has been given to water supply management, causing the community to no longer appreciate this valuable resource.

Water shortage is one of the most natural disasters that will affect the society and a major environmental problem that must be addressed (Rahman, 2014). This study also analyses other factors that might be influencing the water disruption such as maintenance work, water rationing by water managers or suppliers, contaminated water supply, leaking water pipes, prolonged hot weather, and poor attitude on water supply consumption. Moreover, this study also shows the effect that influences water disruption in Penang Island. The finding shows that the most dominant effect of water supply disruption is the disease that affects health and the least influential effect is the reduction in the life of the flora and fauna.

Other effects of water disruption include problems in getting clean water supply affecting the domestic activity, the lack of beverages or drinking resources, poor access to food supplies, poor water quality, and affected economic activity (Connor, 2015). It is important to note that many studies have discussed the factors and effects to water supply related to the issues or research studies in water disruption. However, previous studies show that the most influential factors of water scarcity or water problem are the prolonged hot weather or drought, 
radiation, human density or the growing population, climate change and so on which will lead to several effects such as affected economic growth, human activity, health, water quality and so on.

\section{Conclusion}

The objective of this study is to identify the factors and effects of water supply disruption to the community in Penang Island as reference to local governments to plan strategies to address water problems. The results show that the most dominant factor was due to the lack of capacity of water treatment plant while the most dominant effect was causing reproductive diseases that affect health. The water crisis is due to several factors such as climate, development activities, and so on that affect the society in economic, social, or political sectors and activities. PBAPP has adopted many control methods to ensure uninterrupted water supply services, such as daily dam capacity monitoring, optimising daily drainage, cloud seeding, and encouraging water conservation by users, however this is insufficient if the community is not aware. The community in Penang Island needs to take care and protect the water supply by raising awareness and concern about water issues in order to maintain water sustainability. Clean water quality ensures the well-being of the community. The community also needs to be sensitive and concerned when they see leaking pipes and so on, by reporting to the authorities so that these issues can be addressed immediately.

\section{References}

Ahmed, M. F., Mokhtar, M. B., \& Alam, L. (2020). Factors influencing people's willingness to participate in sustainable water resources management in Malaysia. Journal of Hydrology: Regional Studies, 31, 100737.

Ainsworth, R. (2013). Safe Piped Water: Managing Microbial Water Quality in Piped Distribution Systems. Water Intelligence Online, 12. https://doi.org/10.2166/9781780405841

Anang, Z., Padli, J., Rashid, N. K. A., Alipiah, R. M., \& Musa, H. (2019). Factors affecting water demand: Macro evidence in Malaysia. Jurnal Ekonomi Malaysia, 53(1), 17-25.

Baginda, A. R. A., \& Zainudin, Z. (2009). Moving Towards Integrated River Basin Management in Malaysia. 11th Annual IEM Water Resources Colloquium, 1-9.

Bernama. (2020, May 22). Laksanakan Pembenihan Awam di Penang Island dan Kedah. Astroawani.com. https://www.astroawani.com/berita-malaysia/pbapp-bercadanglaksana-pembenihan-awan-siri-kedua-jun-ini-243997

Biswas, A. K. (2010). Water for a thirsty urban world. The Brown Journal of World Affairs, 17(1), 147-166.

Chan, N. W. (2004). Managing water resources in the 21st century: Involving all stakeholders towards sustainable water resources management in Malaysia. Bangi: Centre for Graduate Studies, Universiti Kebangsaan Malaysia.

Change, I. P. O. C. (2007). Climate change 2007: The physical science basis. Agenda, 6(07), 333.

Chen, Z., Wu, G., Wu, Y., Wu, Q., Shi, Q., Ngo, H. H., ... \& Hu, H. Y. (2020). Water EcoNexus Cycle System (WaterEcoNet) as a key solution for water shortage and water environment problems in urban areas. Water Cycle, 1, 71-77.

Connor, R. (2015). The United Nations world water development report 2015: Wuater for a sustainable world (Vol. 1). UNESCO publishing. 
Dermawan, A. (2019). Penang needs to source raw water from Sungai Perak by 2025. New Straits Times. Retrieved from https://www.nst.com.my/news/ nation/2019/08/516736/penang-needs-source-raw-water-sungai-perak

Dermawan, A. (2020). PBAPP warns of looming water crisis in Penang, Kedah. | New Straits Times. Retrieved from https://www.nst.com.my/news/nation/ 2020/02/565574/pbappwarns-looming-water-crisis-penang.

EPU. (2006). The Ninth Malaysian Plan (2006-2010). Prime Minister's Office of Malaysia. Retrieved from https://www.pmo.gov.my/the-malaysia-plan/

EPU. (2010). The Ninth Malaysian Plan (2011-2015). Prime Minister's Office of Malaysia. Retrieved from https://www.pmo.gov.my/the-malaysia-plan/

Hamid, S. H. A. (2015). A study on the potential of ex-mining lakes as alternative water sources. Doctoral Dissertation, Universiti Malaysia Pahang (unpublished).

Hanafiah, M. M., Ghazali, N. F., Harun, S. N., Abdulaali, H. S., AbdulHasan, M. J., \& Kamarudin, M. K. A. (2019). Assessing water scarcity in Malaysia: A case study of rice production. Desalination and Water Treatment, 149, 274-287. https://doi.org/10.5004/dwt.2019.23841

Hashim, M., Ismail, W. R., Rahaman, Z. A., Nayan, N., Othman, Z., \& Saleh, Y. (2017). Accelerated development and changes in rainfall trends and variations in Malaysia: A case study of the Kinta River basin 1960-2006. Geografia-Malaysian Journal of Society and Space, 12(6), 126-141.

Hezri, A. A. (2018). Urbanization and multiple-scales environmental challenges in Malaysia. In Routledge Handbook of Urbanization in Southeast Asia (pp. 366-374). New York, NY: Routledge.

Husain, M. R., Ishak, A. M., Redzuan, N., van Kalken, T. M., \& Brown, K. (2017). Malaysian National Water Balance System (Nawabs) for improved river basin management: Case study in the Muda River Basin. In E-proceedings of the 37th IAHR World Congress (pp.13-18). Retrieved from https://www.researchgate.net/profile/TerryVanKalken/publication/330751087

Kang, S., Hao, X., Du, T., Tong, L., Su, X., Lu, H., Li, X., Huo, Z., Li, S., Ding, R., (2016). Improving agricultural water productivity to ensure food security in China under changing environment: from research to practice. Agric. Water Manage. 179, 5-17.

Kaur, B., Sidhu, R. S., \& Vatta, K. (2010). Optimal crop plans for sustainable water use in Punjab. Agricultural Economics Research Review, 23(2), 273-284.

KeTTHA. (2009). Kualiti air minum di Malaysia terkawal. Putrajaya: Kementerian Tenaga, Teknologi Hijau dan Air Malaysia (KeTTHA).

Leng, P. W., Weng, C. N., Ghani, A. A., Zakaria, N. A., Jahi, J. M., \& Mokhtar, M. (2013). Tahap kesedaran dan amalan penjimatan air di kalangan pengguna air domestik di Pulau Pinang. In Proceedings of the Prosiding Seminar Serantau Ke-2 Pengurusan Persekitaran di Alam Melayu, Pekanbaru, Provinsi Riau, Indonesia (pp. 6-7).

Omran, A. (2011). Factors influencing water treatment management performance in Malaysia: A case study in Pulau Pinang. Annals of the Faculty of Engineering Hunedoara, 9(1), 53-62.

Osman, S., Abdullah, J., \& Nawawi, A. H. (2017). The financial costs of urban sprawl: Case study of Penang state. Planning Malaysia Journal, 16(6), 13-24. https://doi.org/10.21837/pmjournal.v16.i6.265

Prest, E. I., Hammes, F., van Loosdrecht, M., \& Vrouwenvelder, J. S. (2016). Biological stability of drinking water: controlling factors, methods, and challenges. Frontiers in microbiology, 7, 45.

Rahman, H. A. (2014). Water shortage in Malaysia: Again?. Malaysian Consumer Law Journal, 1, 115-128. 
Ramli, S. (2021). Amaran bekalan air Pulau Pinang tahap satu. Utusan Digital. Retrieved from https://www.utusan.com.my/nasional/2021/03/amaran-bekalan-air-pulau-pinangtahap-satu/, 12 March.

Roderick, M. L., Farquhar, G. D., Berry, S. L., \& Noble, I. R. (2001). On the direct effect of clouds and atmospheric particles on the productivity and structure of vegetation. Oecologia, 129(1), 21-30. https://doi.org/10.1007/s004420100760

Rose, R. A. C., \& Rahimi, N. S. F. (2017). Pemanasan global: Impak dan adaptasi sosioekonomi lokal. Geografi, 5(3), 23-32.

Saeid Eslamian, \& Faezeh Eslamian. (2017). Environmental impacts and analysis of drought and water scarcity. New York: CRC Press.

Sakke, N., Ithnin, H., Ibrahim, M. H., \& Hussain, T. P. R. S. (2016). Kemarau hidrologi dan kelestarian sumber air di Malaysia: Kajian analisis sifat Lembangan Langat, Selangor. Geografia-Malaysian Journal of Society and Space, 12(7), 133-146.

Samian, M., Mahdei, K. N., Saadi, H., \& Movahedi, R. (2015). Identifying factors affecting optimal management of agricultural water. Journal of the Saudi Society of Agricultural Sciences, 14(1), 11-18. https://doi.org/10.1016/j.jssas.2014.01.001

Sani, S. F. M., \& Rindam, M. (2017). Analisis taburan hujan dan impaknya kepada sumber air di Pulau Pinang. Geografia-Malaysian Journal of Society and Space, 7(1), 65-75.

Sophocleous, M. (2004). Global and Regional Water Availability and Demand: Prospects for the Future. Natural Resources Research, 13(2), 61-75. https://doi.org/10.1023/b:narr.0000032644.16734.f5

Tan, C. (2019). Penang's average domestic water tariff is $116 \%$ below the national average. Buletin Mutiara. Retrieved from https://www.buletinmutiara.com/penangs-averagedomestic-water-tariff-is-116-below-the-national-average/\#: :text=Penang

Ternes, T., Joss, A., \& Oehlmann, J. (2015). Occurrence, fate, removal and assessment of emerging contaminants in water in the water cycle (from wastewater to drinking water). Water Research, 72, 1-2. https://doi.org/10.1016/j.watres.2015.02.055

Vorosmarty, C. J. (2000). Global Water Resources: Vulnerability from Climate Change and Population Growth. Science, 289(5477), 284-288. https://doi.org/10.1126/science.289.5477.284 